\title{
Management of the LCC considering industrial construction life cycle contracts
}

\author{
Peter Grabovy and Alexandr Orlov* \\ Moscow State University of Civil Engineering, 129337, Yaroslavskoye shosse, 26, Moscow, Russia
}

\begin{abstract}
Currently the most urgent problem is increasing the efficiency of industrial construction in the green-field and brown-field formats. Introduction of the development method is a typical organizational form of industrial construction management. The method of program management is its variety. The article deals with the analysis of up-to-date strategic aspects of industrial property management. An important task is to create territorial and reproduction systems of industrial property based on life cycle cost (LCC) management. The paper describes the methodical approach to the evaluation of the life cycle cost of industrial property ownership. The evaluation covers the entire life cycle of the property item, from the stage of land development to finished item operation. It is proposed to use life cycle contracts for the development to increase the efficiency of industrial property management. The comparative analysis of life cycle contracts and similar contracts and subcontrator agreements in the area of construction concluded in the territory of Russia showed certain advantages of this approach. The article describes an approach to modeling of an efficient portfolio of industrial development orders. Results of modeling of the structure of the life cycle cost of industrial property ownership as the passive part of fixed funds by functions and stages for the estimated ownership cycle equal to 50 years are presented. Based on the research results the final life cycle cost of ownership for the end user - a resident or owner of the industrial park (IP) industrial property - is determined.
\end{abstract}

\section{Introduction}

The need for a comprehensive review of the impact of various factors enhancing industrial efficiency is an urgent task of improving the economic mechanism in the area of industrial construction and real estate management and development [1-3]. Management improvement is one of the most important issues of construction efficiency and labour productivity [4]. All instruments - economic, organizational, and social - shall facilitate it.

\footnotetext{
*Corresponding author: alor333@gmail.com
} 
In accordance with the report of the Ministry of Construction of the Russian Federation of May 30, 2016, the State Council of the Russian Federation took a decision to ensure completion of industrial construction and commissioning of facilities within the legal time frames by reducing the investment cycle at least twice both during reconstruction and construction of industrial enterprises.

There are two types of industrial parks: a green-field industrial park established on a land plot that was not built-up earlier, is not provided with the engineering and transport infrastructure at the time of project implementation, and a brown-field industrial park based on reconstructed facilities that were intended for a different production function $[5,6]$.

Introduction of the development method (hereinafter referred to as development), one of the varieties of which is the method of program management [7-10], is a typical organizational form of management of such industrial construction.

Development of industrial property (hereinafter referred to as industrial development) should be understood as a type of business activity in the spheres of industrial construction and immovable property as a single land and property complex, which purpose is to generate income (profit) at the expense of organizations for its creation and development that will satisfy needs of the owner and future purchasers to the fullest extent based on the combination of physical, economic and legal processes. Industrial development is the least developed area of commercial property development.

A strategic aspect of management and development in the area of industrial construction and immovable property is the formation of territorial and reproductive industrial property systems $[11,12]$. They should be considered as a special methodological category of economic analysis of industrial construction and immovable property reproductive processes.

According to the data of the Association of Industrial Parks as of January 1, 2018, the number of industrial parks in Russia increased by more than $80 \%$ over the last four years (from 80 in 2013 to 146 in 2018). This growth is due to the existing parks, their number increased more than twofold over the last three years (from 45 to 92). In turn, the number of industrial parks being established remains stable from year to year and fluctuates at the level of 44-56.

In this regard solution of the problem of management of the life cycle cost of IP industrial property is of special importance in the theoretical, methodological and applied aspects [13-15].

Management of the life cycle cost of industrial property in general terms is a set of organizational and management measures aimed at the continuous identification, analysis, evaluation, control and minimization of costs throughout the entire life cycle of industrial park construction and operation.

\section{Management of the life cycle cost of industrial property ownership}

The life cycle cost of industrial property ownership ( $\mathrm{S}_{\mathrm{vld}}$ ) functions through the system of industrial development (DH) divided into land development (DL), investment and construction development (RDH), engineering infrastructure development (DII), transport infrastructure development (DTI) and operational development (DM). In turn, each subsystem presupposes functions (stages), which in the aggregate will give the life cycle cost of industrial property ownership. The general formula is as follows:

$$
\begin{gathered}
S_{v l d}=S\left(f_{[D L]}\right) \rightarrow S^{I}\left(f_{[D L]}\right)+\left(S^{I I}\left(f_{[R D H]}\right)+S^{I I I}\left(f_{[D I I]}\right)+S^{I V}\left(f_{[D T I]}\right)+S^{V}\left(f_{[D M]}\right)\right. \\
\sum_{i=1}^{n} S_{i}\left(f_{[D i]}\right) \rightarrow S_{v l d}(\min )
\end{gathered}
$$


It is proposed to consider traditional rights to contracts in the form of contractor agreements and life cycle contracts for industrial construction when reproducing industrial property $[16,17]$. At the same time the maximum duration of industrial property ownership ( $\left.\mathrm{T}_{\mathrm{vld}}\right)$ for the project initiator (owner) cannot exceed the duration of the whole life cycle of reproduction in the system of industrial development (redevelopment).

All costs related to ownership Svld are divided into two types: nonrecurring costs related to construction and commissioning, as well as costs related to industrial property acquisition on the primary or secondary market; current costs associated with costs incurred by owners from time to time during the period of ownership, including costs for property tax, insurance, major and minor repairs, etc.

Correct and scientifically grounded business planning of activities of real estate investment and development companies is of the highest priority during the construction of industrial park facilities $[18,19]$.

The initiator of the project (owner) and the developer of an industrial park prepare the following fundamental documents - a business plan and a master plan for the construction and operation of facilities and structures, which shall be used by construction contractors.

Planning of industrial park construction should start with calculation of rational methods of construction and selection of optimal methods of industrial complex each phase erection.

Upon consideration of life cycle contracts signed abroad we can come to a conclusion that these contractual systems based on Public Private Partnerships are mostly used for continually moving facilities. However, the area of industrial construction and industrial development has been taking enormous significance in the economy of the Russian Federation and is considered as the national strategic method of increasing industrial competitiveness of the country in the global economy. That is why the use of life cycle contracts for major multi-projects for industrial parks considering the priority evaluation of both the cost of industrial property life cycle and the cost of industrial property ownership should be used as an instrument for prospective and innovative development of industrial construction and industrial development with respect to IP industrial property.

A list of cases for the conclusion of life cycle contracts was approved by Resolution of the Government of the Russian Federation No. 1087 of November 28, 2013. The document was adopted in accordance with Part 16 of Article 34 of the Federal Law of the Russian Federation "On the Contract System in the Sphere of Procurement of Goods, Works, Services for Provisioning Governmental and Municipal Needs" No. 44 FZ of April 5, 2013. The document specifies that life cycle contracts can be used for the procurement of railway cars, vehicles for the subway, out-street transport and city ground-based electric transport, air, sea and river vessels. Also life cycle contracts can be concluded for the design and construction of roads, infrastructure of sea and river ports, airdromes, subway, off-street transport and city ground-based electric transport, railway transport, and unique capital construction projects.

Due to the fact that industrial construction is not yet included in the list of areas where life cycle contracts will be signed, it can be concluded that this issue is rather acute now and requires additional studies and justifications.

Based on the analysis of local experience it follows that the very concept of a life cycle contract implies a contract for the design, construction, financing and maintenance of the 
facility during the entire duration of the contract. The comparative analysis of life cycle contracts and similar contracts and subcontrator agreements in the area of construction concluded in the territory of Russia showed certain features presented in Table 1.

The analysis of data from Table 1 shows advantages of life cycle contracts over similar types of construction contracts that are currently being concluded for financing and ensuring the quality of services in the field of operation.

Table 1. The comparative analysis of life cycle contracts and similar contracts and subcontrator agreements in the area of construction concluded in Russia.

\begin{tabular}{|c|l|l|}
\hline No. & \multicolumn{1}{|c|}{ Contract type } & \multicolumn{1}{|c|}{ Contractor's obligations } \\
\hline 1 & Construction & Construction \\
\hline 2 & Design and construction & $\begin{array}{l}\text { Construction } \\
\text { Construction working project }\end{array}$ \\
\hline 3 & Construction + warranty period & $\begin{array}{l}\text { Construction } \\
\text { Construction working project Warranty } \\
\text { service }\end{array}$ \\
\hline 4 & $\begin{array}{l}\text { Construction and full responsibility for } \\
\text { maintenance and operation }\end{array}$ & $\begin{array}{l}\text { Infrastructure system project (in part) } \\
\text { Construction } \\
\text { Construction working project } \\
\text { Long-term maintenance and operation }\end{array}$ \\
\hline 5 & Life cycle contracts & $\begin{array}{l}\text { Infrastructure system project } \\
\text { Construction } \\
\text { Construction working project } \\
\text { Long-term maintenance and operation } \\
\text { Financing } \\
\text { Ensuring the quality of services }\end{array}$ \\
\hline
\end{tabular}

\section{Modelling of an efficient portfolio of industrial development orders}

At present, the main methods of industrial construction are as follows:

- Industrial method, which presupposes that the maximum possible number of operations for manufacturing, testing, etc. of building structures and equipment is carried out at the factory.

- Construction by structural assemblies, when installation is carried out by means of onsite assembly of larger units and blocks.

- Frame and monolithic construction at the site of multi-project implementation - building structures are made of a metal frame by continuous concreting, equipment and pipelines are assembled at the site of their installation from joints and assemblies.

Each of these methods has its advantages and can be applied in specific conditions for the implementation of industrial construction. For example, when creating the order portfolio a construction company uses closed, open, mixed and combined methods of installation, which constitute the basic methods of industrial construction, for the construction of industrial property facilities.

The closed method is applied for the erection of facilities equipped with process equipment that shall be installed indoors according to the technical conditions. This method provides for installation of process equipment and pipelines after the completion of 
building frame arrangement throughout the whole facility or at its individual sections. It allows installing process equipment by overhead travelling cranes.

The open method provides for installation of the main process equipment and pipelines outdoors. After the completion of works on the installation of process equipment at a separate section of the facility or at the whole facility installation of enclosing structures of the building starts. This method allows increasing the number of free access roads to the equipment installation site, making the installation process easier, and also using inventory tools (winches, gin poles, etc.) instead of heavy-duty cranes.

The process of project portfolio creation by a Russian multifunctional development company consists of a series of general stages, the sequence of which is shown in Fig. 1.

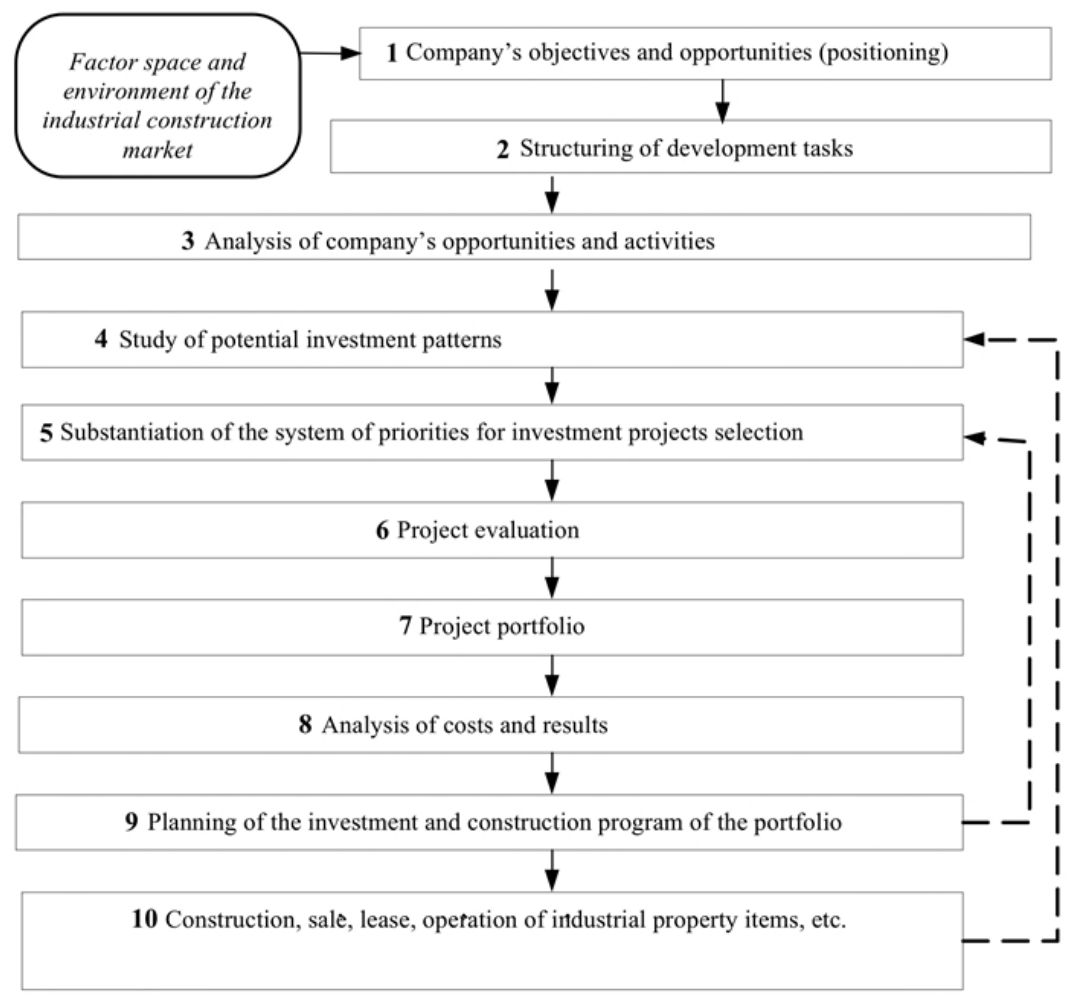

Fig. 1. Planning of the investment and construction program of the portfolio.

The mixed method presupposes installation and erection of bearing structures for equipment, installation of process equipment and pipelines at, at least, one section at the time of works on the building erection.

The combined method is used for projects fitted with equipment, part of which is installed outdoors and the other part of which shall be installed upon completion of the rest construction works at the site according to the technical conditions.

The strategic task of the developer or investment developer is to determine the best possible balanced structure of the investment project portfolio (mono-projects), which requires a comprehensive analysis of regularities and development factors, basically, their oversystem vision.

The authors propose to develop standards for project implementation planning and controlling during the postinvestment period of the life cycle as an individual functional 
procedure of the industrial construction investment regulations. Warranty periods for the construction and assembly works and operation of industrial property and equipment are typical for these standards.

Within the framework of the research the structure of the life cycle cost of industrial property ownership was also studied.

The results of such research are presented in Table 2. It contains the authors' expert and analytical modeling of the structure of life cycle cost of industrial property ownership as the passive part of fixed assets by functions and stages for the estimated life cycle of ownership equal to 50 years.

Table 2. Modeling of the structure of life cycle cost of industrial property ownership as the passive part of fixed assets by functions and stages for the estimated life cycle of ownership equal to 50 years

\begin{tabular}{|c|c|c|c|c|c|c|c|c|c|c|c|c|}
\hline \multicolumn{13}{|c|}{$\begin{array}{l}\text { Life cycle cost of industrial property ownership - } \mathbf{S}_{\mathrm{vdd}}(\mathbf{1 0 0 \%})-\text { for the project } \\
\text { initiator and residents (owners) as the passive part of fixed assets }\end{array}$} \\
\hline \multicolumn{7}{|c|}{ Cost of industrial property $\mathbf{S}_{\mathbf{P N}}=20 \%$ of $\mathbf{S}_{\text {vld }}$} & \multicolumn{6}{|c|}{$\begin{array}{l}\text { Cost of industrial property operation } \\
\qquad \mathbf{S}_{\mathrm{x}}=80 \% \text { of } \mathbf{S}_{\mathrm{VI}}\end{array}$} \\
\hline \multicolumn{5}{|c|}{ Land development (DL) } & \multicolumn{2}{|c|}{$\begin{array}{c}\text { Investment and } \\
\text { construction } \\
\text { development } \\
\text { (redevelopment) } \\
\text { (RDH) }\end{array}$} & \multicolumn{6}{|c|}{ Operational development (DM) } \\
\hline \multicolumn{13}{|c|}{ Estimated life cycle of ownership - 50 years } \\
\hline $0,2 \%$ & \multicolumn{3}{|c|}{\begin{tabular}{|c|c|c|}
$0,5 \%$ & $2,5 \%$ & $1,7 \%$
\end{tabular}} & \multicolumn{2}{|c|}{$15,0 \%$} & $0,1 \%$ & \multicolumn{2}{|c|}{$72,5 \%$} & \multicolumn{2}{|c|}{$0,8 \% 0,2 \%$} & $3,0 \%$ & $3,5 \%$ \\
\hline 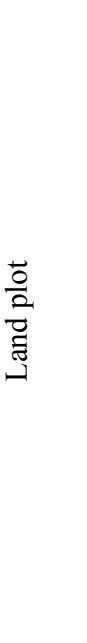 & 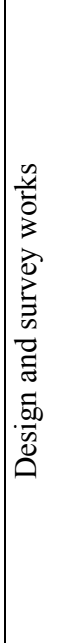 & 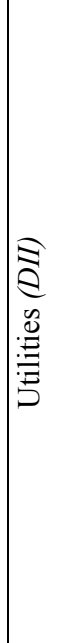 & 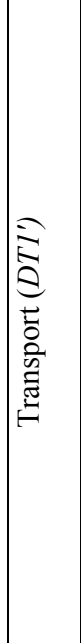 & 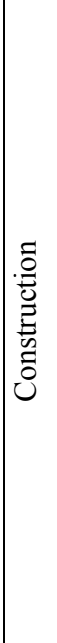 & & 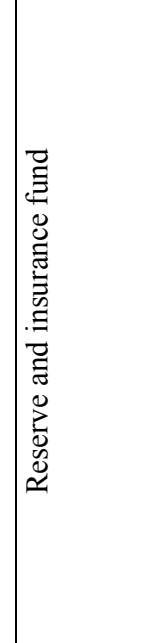 & 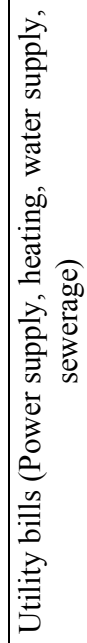 & 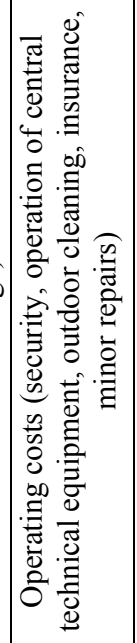 & 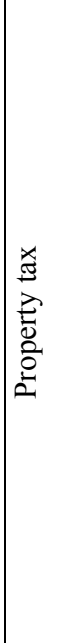 & 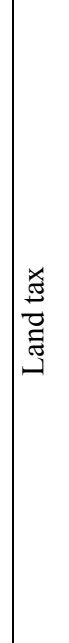 & 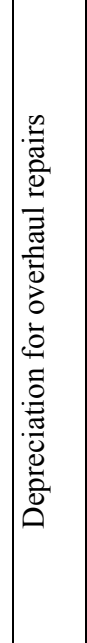 & 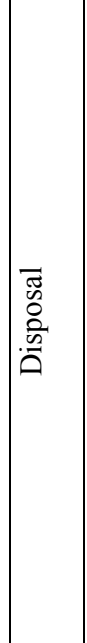 \\
\hline \multicolumn{13}{|c|}{$\begin{array}{l}\text { The index of transformation of the cost of acquired industrial property into the } \\
\text { cost of ownership for the ownership duration of } 50 \text { years: } \mathrm{Ks}=5.0\end{array}$} \\
\hline
\end{tabular}

Within the framework of this research the index of transformation of the cost of acquired industrial property into the cost of ownership for the ownership duration of 50 years was developed. It is equal to $5\left(\mathrm{k}_{\mathrm{s}}=5.0\right)$. It reflects both the regulatory nature of the cost of ownership 1:4 or the ratio of the cost of acquisition $\mathbf{S P N}_{\mathbf{P}}$ and the cost of operation $\mathbf{S}_{\mathbf{x}}$. 


\section{Conclusions}

It is worth pointing out that the structure of the cost of ownership of industrial property as well as other types of property is always unique and specific. Research in this area has started recently and requires comprehensive substantiation and specification. In this regard the proposed structure of the cost of ownership reflects the research experience in industrial park "Stupino Kvadrat" with respect to the property owned by residents cleared from the active part of production assets in the form of equipment which, to a greater extent, relates to dry heated warehouses or leased premises.

The data of the Association of Industrial Parks are used as design data. According to it, during 2016-2018 land cost 102 rubles per square meter or 10.2 million rubles per hectare; the average specific amount of investments made by residents was 310 rubles per square meter or 31 million rubles per hectare.

Due to it the final life cycle cost of ownership for the end user - a resident or owner of IP industrial property - is equal to 1,550 rubles per square meter or 155 million rubles per hectare for the ownership period of 50 years. The multiplier or index of transformation of the cost of acquired industrial property equal to $5\left(\mathrm{k}_{\mathrm{s}}=5\right)$ was used. So, according to TCO international concept the cost of ownership of industrial property can be determined as the sum of the cost of its acquisition for IP residents or the cost of reproduction for project initiators and the cost of its operation at a certain period of ownership for certain subjects of ownership.

\section{Reference}

1. V. Batmanova, A. Zhukov, I. Mitrofanova, World Econ. Intern. Rel. 59 (2), 23-33 (2015)

2. E. Merrow, L. Wallace, Offshore, 76 (1) (2016)

3. E.Merow, Industrial Megaprojects: Concepts, Strategies, and Practices for Success (Wiley, 2011)

4. P. Grabovy, A. Naumov, I.Avilova, Intern. Bus. Manage. 10 (7), 1354-1364 (2016)

5. H. Zhao, S. Guo, H. Zhao, Envir. Dev. Sustain. 20 (3), 1229-1253 (2018)

6. A. Frej, Business Park and Industrial Development Handbook (Urban Land Institute, 2001)

7. M. Miles, L. Netherton, A. Schmitz, Real Estate Development - 5th Edition: Principles and Process (Urban Land Institute, 2015)

8. R. Peiser, D. Hamilton, Professional Real Estate Development: The ULI Guide to the Business, 3rd Edition (Urban Land Institute, 2012)

9. E. Hui, H. Fung, Constr. Manage. Econ. 27 (3), 221-227 (2009)

10. A. Orlov, IOP Conf. Ser.: Ear. Envir. Sci. 90 (1), 012060 (2017)

11. P. Grabovy, A. Orlov, Proceed. Engin. 153, 195-2010 (2016)

12. I. Vazhenina, S. Vazhenin, Econ. Of Reg. 1, 129-136 (2010)

13. P. Gluch, H. Baumann, Build. and Envir. 39 (5), 571-580 (2004)

14. R. Heralová, CESB 2007 PRAGUE International Conference, 1, 105799 (2007)

15. M. Arja, G. Sauce, B. Souyri, Build. Res. Inf. 37 (3), 325-334 (2009)

16. S. Lenferink, T. Tillema, J. Arts, Int. J. Proj. Manage. 31 (4), 615-627 (2013)

17. S. Park, J. Const. Engin. Manage. 135 (11), 1146-1161 (2009)

18. C. Tatum, J. Manage. Engin. 3 (2), 117-126 (1987)

19. C. Park, H. Jang, S. Choi, H. Cho, J. As. Arch. Build. Engin. 9 (1), 25-30 (2010) 